\title{
THE EFFECT OF ESTAFET WRITING TECHNIQUE TO IMPROVE STUDENTS' ABILITY IN WRITING PROCEDURE TEXT
}

\author{
Ida Yulianawati \\ English Education Department_Wiralodra University \\ Ida.yulianawati@unwir.ac.id/ Idayulianawati90@gmail.com
}

\begin{abstract}
This study aimed to know the effect of estafet writing to improve students's ability in writing procedur text. Writing is one of the most important skill that should be mastered by students. But, sometimes the students have difficulties to express their writing because of many factors. The problem that faced by the students in writing are the students have problem in spelling, grammar, punctuation, uninterested media, do not have enough vocabulary so the students repeating the same words, and they often made grammatical errors. Estafet Writing is one of the active learning technique and also an innovative learning model in which one the students starts writing which is continued again one after another. It's one of the techniques that is easy to learn and can be effective way to teach writing procedure text. To achieve the aim of the study, one class of a junior high school in Indramayu with 33 students was taken as the sample of the research. To help students to write procedur texts, estafet writing was used in the classroom. The data were obtained from pre-test and post-test. The result of this research showed that the students' mean score in the pre test is 61.93 and the students' mean score in post test is 81.78 . This study shows that there is improvement of students' ability in writing procedure text and the students give positive responses after being taught by using Estafet Writing Technique.
\end{abstract}

Key words: writing, estafet writing, students' response

\section{INTRODUCTION}

In English, there are four skills that must be mastered by the students, they are listening, speaking, reading, and writing skill. Writing is one of the most important skill that should be mastered by students, as state by Harmer (1998: 79), that "the most important reason for teaching writing, of course, is that it is a basic language skill, just as important as speaking, listening, and reading." Based on 2013 curriculum in junior high school level, the aim of teaching writing is to develop students' ability in oral and written language fluently and accurately in the form of transactional and interpersonal, functional text and short message monologue especially in recount, descriptive, report, narrative, and procedure texts. These kinds of text are taught from grade VII till grade IX.

However, there are many problems in teaching and learning writing, one of the main problems among students is the fact that many of them cannot develop their writing skills. The writing skills are complex and sometimes difficult to teach, requring mastery not only of grammatical and rhetorical devices but also of conceptual and judgement elements (Heaton, 1988). The students also have 
problem in spelling, grammar, punctuation, and teaching method Harmer, 1998). The teaching method is the main causes of their weaknesses in learning writing. Moreover, English language learners have limited vocabulary. Therefore, students end up repeating the same words. Furthermore, the students' writing is difficult to understand because of the ill-structured sentences in composition. Wahyuni (2014) states that the techniques used by the teachers seem to be monotonous because they only used traditional and conventional technique. She also states that the students are not motivated to write a good paragraph; they are still in doubt and confuse to start writing. As state by Harmer (1998: 8), that "whatever kind of motivation students have, it is clear highly motivated students to do better than ones without any motivation at all." It means student's motivation is also important in teaching and learning English. On the other hand, Langan (2009: 35) state that people who believe that writing is a "natural gift" rather than a learned skill may think that they are the only ones for whom writing is unbearably difficult.

Some techniques could be used in teaching writing such as; storytelling, games, puzzles, jumbled story, jigsaw writing, brainstorming, pictures series, reading text, semantic mapping, graffiti, collaborative writing, free-writing, estafet writing etc. Moreover, the teachers must determine what techniques that appropriate for them to be used in teaching because it is related to the activities in the classroom. In addition, in order to increase the quality of English lessons among students, the teacher should be more creative in designing their materials, and have a good skill in arranging the lessons, managing class, and increasing their effectivenes. In this research, the writer wants to apply estafet writing. Estafet writing is one of the ways to stimulate the students to actively participate in writing . The use of this technique also can help students to write more easily because in writing process (Piga,2017), they do it together to exchange information and the writing activity in the classroom also more fun and live.

\section{Research Question}

1. Is estafet writing effective to improve students' ability in writing procedure text?

2. How is the students' response toward the implementation of estafet writing in writing procedure text?

\section{LITERATURE REVIEW Writing}

The writing skills are complex and sometimes difficult to teach, requring mastery not only of grammatical and rhetorical devices but also of conceptual and judgement elements (Heaton, 1988). According to Hague (2002), writing is a process of creating, Organizing, writing, and polishing. On the other hand, Nunan (2003) state that; writing is the mental work of inventing ideas, thinking about how to express them, and organizing them into statements and paragraph that will be clear to readers. Graham and Perin say "writing skill is a predictor of academic success and a basic requirement for participation in civic life and in the global economy. Writing is a combination of process and product (Sokolik, cited in Linse, 2005). 
Writing is important skill to be taught and be mastered by student because there are a lot of reasons in teaching writing (Harmer, 2004:79). Writing is to communicate, to express students' ideas writing is the one of skill effective to learning english, not just how the students want to talk, to read or to listen, but also to write, and writing is not easy to learn, there are many way and many kinds of writing. Hyland (2002:1) and . Harmer, (2007:112) say that writing is central to our personal experience and social identities, and we are often evaluated by our control of it and used as an aide-memory or practice tool to help students practice and work with language they have been studying. Writing is the best way to practice language. To help students express what they want to say slowly in written, and writing is the new experience to learning language especially english.

\section{Writing as Process}

The five-step process writing approach described by Graves (1983) is presented here.

Step 1: Prewriting. The goal here is to generate ideas. Listing, brainstorming, outlining, silent thinking, conversation with a neighbor, or power writing (described below) are all ways to generate ideas.

Step 2: Drafting. Drafting is the writer's first attempt to capture ideas on paper. Quantity here is valued over quality. If done correctly, the draft is a rambling, disconnected accumulation of ideas. Most of the writing activities in the classroom involve just these first two steps. Only those drafts that students feel are interesting or of value should be taken to the next step (Donald Graves calls these hot topics).

Step 3: Revising. This is the heart of the writing process. Here apiece is revised and reshaped many times. The draft stage is like throwing a large blob of clay on the potter's wheel. Revising is where you shape the blob, adding parts, taking parts away, adding parts, and continually molding and changing. Here you look for flow and structure. You reread paragraphs and move things around.

Step 4: Editing. This is the stage where grammar, spelling, and punctuation errors are corrected. A word of caution: The quickest way to ruin a good writing project or damage a writer is to insist that step 4 be included in step 1, 2, or 3 . If writers are editing or worrying about mechanics at the prewriting, drafting, and revising stages, the flow of ideas and the quality of writing suffers. Precious brain space that is devoted to generating and connecting ideas will instead be utilized worrying about writing mechanics.

One last thing about the editing phase: Real writers (of which I am one) edit their writing at the end. Real writers also rely on editors, spell check, and grammar check. In teaching your students to become authors and composers of authentic writing, teach them to approximate the writing process used by real writers. That is, set up peer editing groups and teach students how to use the grammar and spelling functions on a word processor.

Step 5: Publishing and sharing. This is where students' writing is shared with an audience. Writing becomes real and alive at this point. Publishing can involve putting together class books, collections of writing, school or class newspapers, school or class magazines, or displaying short samples of writing in the hall or out in the community. Writing experiences become even more powerful by having 
students read their work out loud in small groups, to another classmate, or in a large group setting.

\section{Genre}

According to Yakonthova (2003), genre is an event of communication, insofar as it is aimed at achieving certain communicative purposes (e.g., the purpose of a birthday card is to congratulate an addressee) and serves as a means of accomplishing such purposes. At the same time, genre may also be defined as a type of a written or oral text with a recognizable set of relatively stable features. Genres may also be treated as textual realizations of discourse.

\section{Kinds of Genre}

There are two kinds of genres, story genre and factual genre. Those kinds of genres have differences in social function, generic structure, and language features.

1) Story Genre

This genre constructed through the process of sequencing people or events in time and space. It involves Narrative, News Story, Exemplum, Anecdote, Recount, and Spoof.

\section{2) Factual Genre}

This genre constructed from many kinds of sequences. Such as constructed through the process of ordering things into commonsense or technical frameworks of meaning, through the process of sequencing phenomena in temporal and/or causal relationships, through the process of logically sequencing actions or behaviours, and through the process of expanding a proposition to persuade readers to accept a point of view. It involves: Procedure, Explanation, Report, Exposition, Discussion, Description, Review, News Item, Commentary'

\section{Procedure Text}

Procedure text is a text that gives some clues how to do something through a series of actions. The main purpose of procedure is to direct, inform or explain. There are diffrent types of procedure texts serving different purposes. Procedure can instruct how to do a particular activity, for example science experiments, stage directions, safety road rules, following an interary and recipes. Procedures can help people by teaching them what is appropriate behaviour for example how to succed. Procedure normally take the form of directions or instructions. Directions depend on someone with knowledge having the skills to pass them accurately, and will direct someone to a place. Instructions will methodically how to make or do something, how something works or how it is used. Example would be instructions manual or operating instructions.Procedural texts communicate the rules, processes or stages for all the above activities. In addition, procedure can be part of mixed text type such as a report on an experiment and can be found in letters, games, phamplets, newspapers, magazine, television, and on sign and maps where they carr the meaning of the text.

\section{Generic Structure of Procedure Text}

In procedure texts the focus is on systematically a logical sequences of actions or steps. Each even or step must be clearly and explicitly written so that the reader 
can carry out the same activity. Text are usually written in the present tense and general terms. Each type of procedure text will have a standard format according to its purpose. Directioins, rules and spoken procedures may have a structure that is slighly different from one explaining how to make something. Written steps can consist of a map with steps that are coded and use arrows, symbol or compass point. Alternatively, the steps can be written in note form with illustration, diagrams, cartoons, flow charts, and photos clarifying the meaning. Other text type, for example description and explanations can be found within these text.

The stucture usually consists of three stages:

a. An introductory statement that gives the heading the goal or the aim of the activity and state what proceure is aiming to achieve. Sometimes the goal is indicate in the main heading for example, 'Building a Model of Dinosaur'. This maybe added by diagram or map.

b. The listing of material or equipment to be used for the procedure.

c. The method or sequence of steps written in the order in which they should be completed.

Each stage play a role in explaining what we need or what precisily waht we have to do next. Each steps is ordered and sometimes numbered. Some procedure have an optional that explain reasons for steps and will offer alternative methods. The text may include comments, or warnings about dangerous aspect and consequences, or describe enjoyoable aspect of the task. Hint or warning can be add in defferent points for example, 'take care when picking up the sharp point.

\section{Language Features of Procedure Text}

a. Noun or noun groups are used in the listed material or equipment e.g. screws, nuts, bolt, screwdriver, wood.

b. Often the name of item is omitted instead being constantly repeated and an ellipsis is used. The person following the instructions may not be reffered to or may be referred to in general way as one or you. There is little use of personal pronouns.

c. Conjunctions are used to show chronological order. e.g. before, while, then, after, when.

d. Action verbs start most sentences. e.g. put, take, link.

e. Short statement or commands are used.

e.g. put them up.

f. Adjectives add details relating size, shape, colour, and amount e.g. place the red cube there.

g. Word related to directions and specific location are found. e.g. left, north, Jamison Street.

h. Present tense is generally used.

i. Vocabulary ranges from technical to eveyday language accordning to the target audience.

j. Emphasis is often given to important information by underlining it or writing in bold.

k. Adverbs, prepositions and adverbial phrase add detailed information about how, when and where.

1. Clear, simple, precise but detailed language is used 


\section{Estafet Writing \\ General Concept of Estafet Writing}

Estafet writing is one kind of technique to teach English, especially teaching writing. According to Sitti Syathariah, estafet writing is one kind of active learning or learning by doing that has purpose to make students associate learning as a fun activity. According to Indarto (2013), Estafet is a game which is adopted from estafet race. The meaning of the word estafet itself is 'connected to each other'. In this study, estafet writing is made as a technique in teaching English.

The rules both of them are same; the members of group should take a part to finish the assignment. In Estafet writing, the members of group must write a paragraph one by one. So that, all of those paragraphs that were written by the group members will be a text.

\section{Applying Estafet Writing in Teaching Procedure Text}

In this research, the writer tried to find out an appropriate technique to teach writing procedure text for students of junior High School. The writer used Estafet Writing as a technique. Through a technique, teacher can improve the students' achievement in learning writing procedure text and the learning process will be more enjoyable and interesting. They will get new atmosphere in learning writing. The Step of Estafet Writing Technique:

a. Teacher divides students into some groups. Every group consists of 6-8 students.

b. Teacher gives explanation about the rule of the technique, and give the topic (a goal) of a text to each group, then teacher asks the first students to write first sentence based on the goal of the text.

c. When the first student finish write first sentence, distribute the paper to the right-side student. Next student should continue to write sentence and so on until the sentences be a text. Students also have to write their name after finishing their sentence in the end of their sentence.

d. After finishing all of sentencess, all of group members have to revise their work together.

\section{The advantages of Estafet Writing in Teaching Procedure Text}

Teaching writing procedure text will be more effective by using Estafet Writing because it will make learning atmosphere funnier and not boring. Estafet writing will make students to be free drawing their ideas in a text. Syatariah states that Estafet writing is one kind of effective technique which can improve students' motivation in developing their imagination to write a text and growing up the students' braveness in starting their imagination to write a text.

So, through Estafet writing students will be motivated to learn writing a text and it will also give positive impact to students' writing skill. Estafet writing can be an effective technique to teach English, because using this technique the students will learn writing in a group but they still also have a chance to improve their writing ability individually. Estafet writing also gives a chance for all member of group to revise their work together. 


\section{RESEARCH METHODOLOGY}

\section{Data Collection}

This research is a pre-experimental research method. According to Wray, Trott, and Bloomer (1998: 160), "Experimental data is much more focused than, say, a recording of spontaneous speech or informal interview/activity data, so it is easiest to make sense of, to process and evaluate." And to focus the kinds of experiment, the writer uses Pre-experimental design to know the effect of picture-cued activities in improving students' writing ability. According to Hatch and Farhady (1982:19). In pre-experimental design, there are three designs and the writer has chosen onegroup pre-test posttest design to this pre-experimental research. The design is represented below:

$\mathrm{T}_{1} \times \mathrm{T}_{2}$
$\mathrm{~T}_{1}:$ pre-test
$\mathrm{T}_{2}:$ post-test
$\mathrm{X}:$ treatment

In this research, the writer uses quantitative approach to analyze the data of research, because this research need a specific, clear, and detail information or result, and also this research media has been prepared and decided. To get the specific data the writer uses experiment as a method in this research. It is used to make sure the effect of picture cued activities in improving students' writing

\section{Participants of the study}

The participants of the study was 33 eighth grade students of a junior high school in Indramayu. The study was conducted from November to December 2018.

\section{Instrumentation}

The functions of the instrumentation are to collect and evaluate the data. The writer use two instruments, they are: The test that used to measure the students' achievement in writing procedure text before and after taught by using estafet writing. Test gives in two kinds: pre-test and post-test. Pre-test will give before applied the technique. The writer also give post-test in every cycle to measure the students' achievement on writing procedure text after being taught by using estafet writing, and questionnaire to collect data in field setting, and the data themselves are more amenable to quantification than discursive data such as free-form field notes, participant observers' journals, the transcript oral language. According to Brown (as cited in Dornyei, 2003), Questionnaires are any written instruments that present respondents with a series of questions or statements to which they are to react either by writing out their answers or selecting from among existing answers. On the other hand, Nunan (1992) state that the questionnaire is relatively popular means of collecting data.

\section{Data Analysis and Interpretation Technique}

1. Test

In the quantitative data analysis, the writer gets the data from the test result. To analyze the statistical data, the writer puts on the average of students' ability 
in writing procedure text score per action in each cycles, it uses formula as follow:

$$
M=\frac{\Sigma \mathrm{X}}{N}
$$

Note: $\mathrm{M} \quad=$ Mean

$\Sigma \mathrm{X}=$ The amount of students' score

$\mathrm{N} \quad=$ Number of students

After that, the writer tries to get the class percentage which pass the minimum standard score (KKM), the writer uses the formula:

Note:

$$
P=\frac{f}{N} \times 100 \%
$$

$$
\begin{array}{ll}
\mathrm{P} & =\text { The class percentage } \\
\mathrm{f} & =\text { the number of students who passed KKM } \\
\mathrm{N} & =\text { The number of students }
\end{array}
$$

2. Questionnaire

Data from questionnaire is used by the writer to find out the students' responses after being taught by using estafet writing. In analyzing this data, the writer categorize every question in questionnaire into two alternative responses, there are Yes and No. The following are score for every alternative response:

1) Yes is the answer when the students agree with the question in questionnaire. Score for this response is 1 .

2) No is the answer when the students disagree with the question in questionnaire. Score for this response is 0 .

Then, to know the data of questionnaire, it uses the formula as follows for each number of questions:

Score $=\frac{\text { number of students } \text { who selected "yes" }}{\text { total number of students }} \times 100 \%$

To know the criteria of students' responses after being taught by using Estafet Writing it can be classified into the category as follows:

Table 3.3

The Interpretation of Students' Questionnaire

\section{A. Description of Research Data}

\begin{tabular}{|c|c|}
\hline Score & Criterion \\
\hline $81 \%-100 \%$ & Excellent \\
\hline $61 \%-80 \%$ & Good \\
\hline $41 \%-60 \%$ & Average \\
\hline $21 \%-40 \%$ & Fair \\
\hline $0 \%-20 \%$ & Poor \\
\hline
\end{tabular}

In conducting this pre experimental research, there were some data which have been collected. They are data from writing test, and and questionnaire. 
Test was given in two times; pretest and posttest. The test result would give information about the improvement of students' ability in writing procedure text. The aim of the pretest is to know the initial score of the students' writing ability before taught by using estafet writing technique. In the last meeting, the writer reviewed the last material. Then, the writer gave post test to the students. The students were assigned to arrange the jumbled sentences into a correct procedure text and they also had to write a short simple procedure text based on their experiences. After the students finished the test, the writer gave questionnaire to the students, the questions are 1). Do you like the English learning process using Estafet Writing? 2). Do you feel more enjoyed in learning English using Estafet Writing? 3). Are you enthusiastic learning Procedure text using Estafet Writing? 4). Do you want to be more active in learning Procedure text using Estafet Writing? 5). Do Estafet Writing can help you to make a good cooperation with your team in learning Procedure text? 6). Do Estafet Writing can help you to build your responsibility in team? 7). Do Estafet Writing can help you to comprehend the material about Procedure text? 8). Do you feel easier in writing Procedure text after being taught by using Estafet Writing? 9). Could you produce a better Procedure text after being taught by using Estafet Writing? 10). Will you be more active in English learning process? The purpose of this questionnaire is to know the students' responses after being taught writing procedure text by using estafet writing technique. The result of data will be explained below:

\section{Data from Pretest}

The pre test was conducted November 2018. There are 30 students in the class, and 3 students are absent. After got data from test, the writer calculated the students' mean score and the students' percentage who achieve the minimum standard score. The calculation shows that the students' mean score of preliminary test was 61.93 . The highest score was 75 and the lowest score was 25 . It can be seen from the table below:

$\begin{array}{cccccccccc}\text { Table } & \text { 4.1 Students' } & \text { Test } & \text { Results } & \text { of the Preliminary Test } \\ 75 & 75 & 75 & 75 & 75 & 75 & 70 & 66 & 66 & 66 \\ 66 & 60 & 60 & 65 & 58 & 58 & 58 & 58 & 58 & 58 \\ & & & & & & & & & \\ 58 & 58 & 50 & 50 & 50 & 50 & 50 & 50 & 50 & 25\end{array}$

From the table above, it can be seen that the highest score in the preliminary test was 75 , there were six students who got it. Three students got 66 , three students got 60 , one students 65 , eight students got 58, seven students got 50, and one students got the lowest score 25 . There were only $20 \%$ or six students who passed the minimum standard score (KKM) 75. In analyzing the data of test, the first step is to get the mean score of the test. It is calculated by using this formula:

$M=\frac{\Sigma \mathrm{X}}{N}$ 
$\boldsymbol{M}=\frac{1858}{30}$

$M=61.93$

After calculated the students' mean score, the writer calculated the students' percentage who achieved the minimum standard score (KKM) 75 , It is calculated by using this formula:

$$
\begin{aligned}
& \boldsymbol{P}=\frac{\boldsymbol{f}}{\boldsymbol{N}} \times 100 \% \\
& \boldsymbol{P}=\frac{6}{30} \times 100 \% \\
& \boldsymbol{P}=20 \%
\end{aligned}
$$

The result of this test was not satisfying yet. The problems that faced in this meeting were the evidence of genre characteristic, like the use helpful tips. Grammar, usage, and mechanics like the use of grammar especially in the tense, complete sentences including command, correct use of articles (a/an/the), correct punctuation, capitalization, and spelling. Then the writer was aware that most of students in VIII B still have difficulties in arranging a good procedure text. The writer intended to use estafet writing technique to the next activity to make students interest and enjoy the learning process so that their writing score would be better.

\section{Data from Posttest}

$$
\begin{aligned}
& \boldsymbol{M}=\frac{\Sigma \mathrm{X}}{\boldsymbol{N}} \\
& \boldsymbol{M}=\frac{2617}{32} \\
& \boldsymbol{M}=81.78
\end{aligned}
$$

From that calculation, the mean score of the post test is 81.78. It means that there were more students' improvement score. The next step is to know the students' percentage who achieved the minimum satndard score (KKM) 75. It is used formula as follow:

$$
\begin{aligned}
& \boldsymbol{P}=\frac{\boldsymbol{f}}{\boldsymbol{N}} \times 100 \% \\
& \boldsymbol{P}=\frac{26}{32} \times 100 \% \\
& \boldsymbol{P}=81.25 \%
\end{aligned}
$$

The calculation showed that there are $81.25 \%$ students who achieved the minimum standard score (KKM) 75. It means that there were twenty six (26) students who acheived the minimum standard score (KKM) 75, and six (6) students are below the minimum standard score (KKM) 75. 
Table 4.4 The Result of Students' Test

\begin{tabular}{|c|c|c|c|}
\hline \multirow{2}{*}{ No. } & \multirow{2}{*}{ Students' Code } & \multicolumn{2}{|c|}{ Students' Test Score } \\
\hline & & Pre-test & posttest \\
\hline 1. & S-01 & 66 & $90 *$ \\
\hline 2. & S-02 & 58 & $78 *$ \\
\hline 3. & S-03 & $75^{*}$ & $85^{*}$ \\
\hline 4. & S-04 & 58 & $90 *$ \\
\hline 5. & S-05 & 50 & $80 *$ \\
\hline 6. & S-06 & 50 & 73 \\
\hline 7. & S-07 & 58 & $88 *$ \\
\hline 8. & S-08 & 70 & - \\
\hline 9. & S-09 & 50 & $83 *$ \\
\hline 10. & S-10 & 58 & $83 *$ \\
\hline 11. & S-11 & 58 & $88^{*}$ \\
\hline 12. & S-12 & $75^{*}$ & $85^{*}$ \\
\hline 13. & $S-13$ & 25 & 71 \\
\hline 14. & S-14 & 60 & $78 *$ \\
\hline 15. & $\mathrm{~S}-15$ & - & $85 *$ \\
\hline 16. & S-16 & 65 & $78 *$ \\
\hline 17. & S-17 & 58 & $83 *$ \\
\hline 18. & S-18 & 50 & 73 \\
\hline 19. & S-19 & 50 & $88 *$ \\
\hline 20. & S-20 & 66 & $90 *$ \\
\hline 21. & S-21 & 58 & $78 *$ \\
\hline 22. & S-22 & 66 & $83^{*}$ \\
\hline 23. & S-23 & $75^{*}$ & $85^{*}$ \\
\hline 24. & S-24 & 50 & 71 \\
\hline 25. & S-25 & $75^{*}$ & $85^{*}$ \\
\hline 26. & S-26 & 60 & $88 *$ \\
\hline 27. & S-27 & $75^{*}$ & $85^{*}$ \\
\hline 28. & S-28 & 50 & $80 *$ \\
\hline 29. & S-29 & $75^{*}$ & $83 *$ \\
\hline 30. & $\mathrm{~S}-30$ & 66 & $90 *$ \\
\hline 31. & S-31 & - & $76^{*}$ \\
\hline 32. & S-32 & 58 & 71 \\
\hline 33. & S-33 & - & 73 \\
\hline \multicolumn{2}{|c|}{ Total Score } & 1858 & \\
\hline \multicolumn{2}{|c|}{ Mean } & 61.93 & \\
\hline
\end{tabular}

*The students who passed the minimum standard score (KKM) 75.

It can be seen from the table above that in pretest there were only 6 (six) or $20 \%$ students who achieved the minimum standard score (KKM) 75, and improved in cycle 2 became 13 (thirteen) or $48.14 \%$ students who achieved the minimum standard score (KKM) 
75 , and became twenty six (26) or 81.78 students who achieved the minium standard score (KKM) 75 in cycle 2.

The students' mean score improved in in post test from 61,93 to 81.78 in cycle 2 . From the result above the writer can conclude that estafet writing technique effective to improve students' ability in writing procedure text.

\section{The result of Questionnaire cycle 2}

The questionnaire was given to the students on Friday, $25^{\text {th }}$ November 2016. The following was the table of students' questionnaire result in cycle 2 :

Table 4.5 The result of Questionnaire Cycle 2

\begin{tabular}{|c|c|c|}
\hline \multirow{2}{*}{$\begin{array}{l}\text { Number of } \\
\text { Question }\end{array}$} & \multicolumn{2}{|c|}{ Total of Students } \\
\cline { 2 - 3 } & YES & NO \\
\hline 1 & 32 & 0 \\
\hline 2 & 32 & 0 \\
\hline 3 & 32 & 0 \\
\hline 4 & 32 & 0 \\
\hline 5 & 31 & 1 \\
\hline 6 & 32 & 0 \\
\hline 7 & 31 & 1 \\
\hline 8 & 31 & 1 \\
\hline 9 & 32 & 0 \\
\hline 10 & 32 & 0 \\
\hline
\end{tabular}

In analyzing the data from questionnaire, it used the formula as follows for each questions:

$$
\text { Score }=\frac{\text { number of students } \text { who selected }}{\text { "yes" }}=100 \%
$$

The following was the description of the result of questionnaire:

a. The students like the English learning process using estafet writing technique.

The result of first question showed that $100 \%$ the students answer "Yes" or 32 students like the English learning process using estafet writing technique. Based on the interpretation of students' questionnaire if the answer showed 100\% it was excellent.

b. The students feel more enjoyed in learning English using estafet writing technique.

The result showed that $100 \%$ the students answer "Yes" or 32 students more enjoyed in learning English using estafet writing 
technique. Based on the interpretation of students' questionnaire if the answer showed $100 \%$ it was excellent.

c. The students are enthusiastic learning procedure text using estafet writing technique.

The result showed that $100 \%$ the students answer "Yes" or 32 students were enthusiastic leraning procedure text using estafet writing technique. Based on the interpretation of students' questionnaire if the answer showed $100 \%$ it was excellent.

d. The students want to be more active in learning procedure text using estafet writing technique.

The result showed that $100 \%$ the students answer "Yes" or 32 students want to be more active in learning procedure text using estafet writing technique. Based on the interpretation of students' questionnaire if the answer showed $100 \%$ it was excellent.

e. Estafet writing technique can help the students to make a good cooperation with their team in learning procedure text.

The result showed that $96 \%$ the students answer "Yes" or 31 students agree that estafet writing technique can help them to make a good cooperation with their team in learning procedure text. Based on the interpretation of students' questionnaire if the answer showed $96 \%$ it was excellent.

f. Estafet writing technique can help the students to build their responsibility in team.

The result showed that $100 \%$ the students answer "Yes" or 32 students agree that estafet writing technique can help them to build their responsibility in team. Based on the interpretation of students' questionnaire if the answer showed $100 \%$ it was excellent.

g. Estafet writing technique can help the students to comprehend the material about procedure text.

The result showed that $96 \%$ the students answer "Yes" or 31 students agree that estafet writing technique can help them to comprehend the material about procedure text. Based on the interpretation of students' questionnaire if the answer showed $96 \%$ it was excellent.

h. The students feel easier in writing procedure text after being taught by using estafet writing technique.

The result showed that $96 \%$ the students answer "Yes" or 31 students feel easier writing procedure text after being taught by using estafet writing technique. Based on the interpretation of students' questionnaire if the answer showed $96 \%$ it was excellent.

i. The students can produce a better procedure text after being taught by using estafet writing technique.

The result showed that $100 \%$ the students answer "Yes" or 32 students can produce a better procedure text after being taught by using estafet technique. Based on the interpretation of students' questionnaire if the answer showed $100 \%$ it was excellent.

j. The students will be more active in English learning process. 
The result showed that $100 \%$ the students answer "Yes" or 32 students will be more active in English learning process. Based on the interpretation of students' questionnaire if the answer showed $100 \%$ it was excellent.

\section{B. Discussion}

The data result that gained from pretest and posttest showed that there were improvement towards students' ability in writing procedure text after the implementation of estafet writing technique. It showed that estafet writing technique could help them to write a better procedure text. This section will describe the discussion how the implementation of estafet writing technique improves the students' ability in writing procedure text by comparing the students' test result from preliminary test, test of cycle 1 and cycle 2 .

The students' vocabulary progress showed by the result from preliminary test which have the mean of 62.93 to 81.78 in posttest. The students' percentage who achieved the minimum standard score (KKM) 75 from pretest was $20 \%$ or only six (6) students who passed the minimum standard score, and $81.25 \%$ or twenty six (26) students who passed the minimum standard score posttest. This data shows that there was any improvement in the students' test result even though there were any some students who got the score under average, but overall the students test result are improved. Below are some example of the improvement of students' writing. In this case, the writer will discuss some students who got the highest score, the lowest score, and also the students who have many progress.

First, there was one of the students (S25) who got the highest score (75) in the pretest. Her score in posttest improve to 86. In the other case, there was a student (S30) who got 66 in pretest, it means that she didn't pass the KKM but made a great improvement in post test (90). A student (S13) who got the lowest score in the pre test (25), she got 71 in post test.

There was a student (S01) who didn't pass the KKM in the preliminary test, but she made an improvement after the implementation of estafet writing. Her score is 90. There was a student (S19) who has the similar case with (S01) but the different was he got 50 in pre test, but improved to 88 . In posttest. It was significant improvement. Moreover, students S03, S12, and S29 made many progress in their writing in term of schematic structures and linguistics features of the text. Grammar, usage, and mechanics like the use of grammar especially in the tense, complete sentences including command, correct use of articles (a/an/the), correct punctuation, capitalization, and spelling were also become the attantion of this study.

The students' response to the questionnaire showed that almost $100 \%$ students agreed that estafet writing technique could help them to write a better procedure text. It means that there were students positive responses about estafet writing technique.

Based on the data discussion above, the students showed their improvement after the teacher implement estafet wriring in teaching 
procedure text. Thus, it can be said that estafet writing is effective to improve students' ability in writing narrative text.

\section{REFERENCES}

Bailey, Stephen. (2008). Academic Writing: A Handbook for International Students. (2nd ed.). New York: Routledge.

Brown, H. Douglas. (2003). Language Assessment Principles and Classroom Practice, London: Longman.

Depdiknas. (2006). Standar Isi dan Standar Kompetensi Lulusan: Mata Pelajarn Bahasa Ingggris (SD/MI,SMP/MTs, SMA/MA, MA/MAK). Jakarta: Depdiknas.

Dornyei, Zoltan. (2003). Questionnaires in Second Language Research. London: Lawrence Erlbaum Associates, Inc.

Graham, Steve., \& Perin, Dolores. (2007). Writing Next: Effective Strategies To Improve Writing Of Adolescents In Middle And High Schools. New York: Corporation of New York.

Graves, Donald H. (1983) Writing: Teachers and children at work. Portsmouth: Heinemann.

Harmer, Jeremy. (1998). How to Teach English. Edinburgh: Longman.

Heaton, J. B. (1975). Writing English Language Test. United State of America: Longman Inc.

Hyland, Ken. (2009). Teaching and Researching Writing, $2^{\text {nd }}$ ed. UK: Pearson Education Limited.

http://assets.readingeggsassets.com/teacher_resources/rex/writing/pdfs/middle/pro cedure_texts_introduction_and_overview-fp-9569b444.pdf. Retrived May, 5 th 2016

Indarto, H. D. (2013). Analisa Lari Estafet Retrieved May 4th, 2016, from www.det.nsw.edu.au/eppcontent/glossary/app/resource/factsheet/4108.pdf

Johnson, A. P. (2008). Teaching Reading and Writing: A GuideBook for Tutoring and Remediating Students. United State of America: Rowman \& Littlefield Publishers, Inc.

Kemmis, Stephen \& McTaggart Robin. (2007). Participatory Action Research. Journal of Action Research. 4 (12). 271-330.

Langan, John. (2010). Exploring Writing: Sentences and Paragraph. (2nd ed.). New York: McGraw-Hill Companies, Inc.

Latief, Adnan. (2009). Penelitian Tindakan Kelas Pembelajaran Bahasa Inggris. Malang: Universitas Negeri Malang. 
Linse, Caroline T. (2005). Practical English Language Teaching: Young Learner. New York: McGraw-Hill Companies, Inc.

Mettetal, Gwynn. (2001). The What, Why and How of Classroom Action Research. The Journal of Scholarship of Teaching and Learning (JoSoTL) 2 (1): $1-13$.

Nunan, David. (1992). Research Method in Language Learning. New York: Cambridge University Press.

Nunan, David. (2003). Practical English Language Teaching. New York: McGraw-Hill Companies, Inc.

Piga, Gabriel Hibu. 2017. Improving the Eleventh Grade Students of SMAN I Raiju in writing narrative test through estafet writing teaching model. International Journal of English Education. ISSN: 2278-4012, Volume:6, Issue:4, October 2017.

Richard, J. C., \& Schmidt, R. Dictionary of Language Teaching \& Applied Linguistic. Longman.

Syatariah, S. (2009). Menulis Berantai Sebagai Metode Inovatif. Pekanbaru: CPI Rumbai.

Syathariah, Sitti. (2011). Estafet Writing. Yogyakarta: Leutikaprio.

Weigle, Sara Cushing. (2011). Assessing Writing, Cambridge: Cambridge University Press.

Yakonthova, T. V. (2003). English Academic Writing. United State: University of Oregon. 